\title{
Heterologous expression of an acidophilic multicopper oxidase in Escherichia coli and its applications in biorecovery of gold
}

Shih-I Tan ${ }^{1}, \mathrm{I}-\mathrm{Son} \mathrm{Ng}^{1,2^{*}}$ and You-Jin Yu${ }^{1}$

\begin{abstract}
Background: Copper oxidase is a promising enzyme for detection of oxidation, which can function as a biosensor and in bioremediation. Previous reports have revealed that the activity of the multicopper oxidase (MCO, EC 1.10.3.2) from the Proteus hauseri ZMd44 is induced by copper ions, and has evolved to participate in the mechanism of copper transfer.

Results: From P. hauseri ZMd44, a full-length, 1497-base-pair gene, lacB, encoding 499 amino acids without signal peptide, was cloned into Escherichia coli (E. coli) to obtain high amounts of MCO. The use of the pET28a vector yielded better enzyme activity, which was approximately 400 and $500 \mathrm{U} / \mathrm{L}$ for the whole cell and soluble enzyme extracts, respectively. The crude enzyme showed activity at an optimal temperature of $55^{\circ} \mathrm{C}$ and it remained highly active in the range of $50-65^{\circ} \mathrm{C}$. The optimal pH was 2.2 but the activity was significantly inhibited by chloride ions. This MCO has great potential for Au adsorption (i.e., 38\% w/w) and the Au@NPs were directly adsorbed on enzyme's surface.

Conclusion: An acidophilic MCO from bioelectricity generating bacterium, P. hauseri, is first cloned and heterologously expressed in E. coli with high amounts and activity. This MCO has great potential for Au adsorption and can be used as a biosensor or applied to bioremediation of electronic waste.
\end{abstract}

Keywords: Multicopper oxidase, Proteus hauseri, Recombinant protein, Copper effect, Au adsorption

\section{Background}

The enzyme multicopper oxidase (MCO) is a type of laccase (EC 1.10.3.2) that has important industrial applications owing to its oxidizing and degrading activities on a wide variety of aromatic compounds (Mayer and Staples 2002; Claus 2003; Rodgers et al. 2010). For instance, laccases are used in the process of paper-pulp bleaching to degrade lignin (Larsson et al. 2001). Furthermore, MCO, as one of laccases, has a high demand in different manufacturing processes such as wine production, medical analysis, electrochemical detection (Li et al. 2015), bioremediation (Santhanam et al. 2011), and gold nanoparticle preparation (Guo et al. 2015).

\footnotetext{
*Correspondence: yswu@mail.ncku.edu.tw

${ }^{1}$ Department of Chemical Engineering, National Cheng Kung University, Tainan 70101, Taiwan

Full list of author information is available at the end of the article
}

Proteus hauseri strain ZMd44 is a gram-negative bacterium with outstanding performance in biodecolorization of azo-dyes (Ng et al. 2013), and has been used in the microbial fuel cell (MFC) system (Chen et al. 2010, 2012). In addition, its MCO-laccase activity of $357 \mathrm{U} / \mathrm{L}$ at optimal cultivation condition was induced by copper (Zheng et al. 2013). Furthermore, this MCO-laccase participates in the transport of copper ions from the medium to the cells (Grass and Rensing 2001). By whole genome sequencing, it has been found that $P$. hauseri $\mathrm{ZMd} 44$ possesses LacA and LacB (Wang et al. 2014). However, genetic engineering of any laccase or multicopper oxidase from the Proteus genus has not been illustrated in the literature thus far. Owing to the insufficient enzyme production by naturally occurring microbes, heterologous expression of the laccase genes via $E$. coli cloning is urgently required. 
Genetic heterologous expression may be influenced by different factors, including protein structure (Gopal and Kumar 2013), effect of bacterial strain (Moreira et al. 2014), and the use of different expression vectors (Rosano and Ceccarelli 2014). In general, the most common plasmid used in recombinant engineering of $E$. coli is the pET system, owing to its strong expression levels. In this study, three different vectors, pET22b, pET28a, and pET32a, are used to produce recombinant MCO. All the vectors contain the same $\mathrm{T} 7$ promoter, and the resulting proteins are fused to a 6-Histidine tag for protein affinity purification. While pET28a is a vector in which recombinant protein would be overexpressed intracellularly, the $\mathrm{pET} 22 \mathrm{~b}$ vector includes a signal peptide, $p e l \mathrm{~B}$, so that the recombinant protein is secreted to the periplasam. Finally, vector pET32a contains a fusion protein, TrxA, which works as a chaperone to assist in protein folding and to enhance soluble protein expression (Baneyx and Mujacic 2004).

Over the past decades, the number of consumers using electronic devices manufactured by the semiconductor industry is rapidly increasing, resulting in the accumulation of a huge amount of electronic waste (Natarajan and Ting 2014, 2015). Routine recovery of gold ( $\mathrm{Au}$ ) from industrial metal waste is expensive. Further, biotechnology industries are taking eco-friendly approaches to recover metals from waste, which have significantly contributed to control the pollution in the environment. Previous studies showed Proteus spp. (Chen et al. 2010, 2012) and Shewanella spp. (Ng et al. 2014, 2015) with good performance in biodecolorization and metal absorption, but they never been used of genetic approach. Therefore, the use of genetically engineered MCO for bioremediation is a promising and cost-effective solution.

Until now, only few research studies have explored the heterologous expression of MCO in E. coli. This is the first attempt to determine the optimal vector to express
MCO. Additionally, the optimal reaction conditions, including temperature, $\mathrm{pH}$, and ion effect, were assessed. Finally, the use of the recombinant MCO in Au adsorption and gold nanoparticle (Au@NPs) preparation, and its catalytic activity, were also explored.

\section{Methods}

Cloning and construction of recombinant LacB in E. coli

All cloning was performed in E. coli strain DH5a. Reagents used in polymerase chain reaction (PCR), including long and accurate LA-Taq DNA Polymerase, PCR-grade dNTPs, restriction enzymes, T4 DNA ligase, and DNA ladder marker, were obtained from Takara (Dalian, China). PCR products and restriction-digested DNA were purified by DNA gel extraction and PCR cleanup kits (Axygen). Genomic DNA was isolated from $5 \mathrm{~mL}$ of overnight cultures at $37^{\circ} \mathrm{C}$ in LB broth, using bacterial genomic DNA miniprep Kit (Axygen). The entire open reading frames of $l a c B$ were amplified with primers shown in Table 1, using genomic DNA from the ZMd44 as DNA template. The resulting PCR products were inserted between the $\mathrm{T} 7$ promoter and the terminator in the vectors pET32a, pET28a, and pET22b, and introduced into E. coli BL21(DE3) cells, as shown in Fig. 1a-c. Recombinant colonies grown on LB plates with corresponding antibiotics (i.e., kanamycin or ampicillin) were verified by colony PCR and double enzymatic digestion with NcoI and XhoI. All strains, plasmids, and primers used in this study are shown in Table 1.

Culture and heterologous expression of recombinant MCO The expression host BL21 (DE3) harboring the recombinant ZMd44-lacB vector was cultivated in LB medium with corresponding antibiotics and agitation $(200 \mathrm{rpm})$ at $37{ }^{\circ} \mathrm{C}$. Once the cultures reached a biomass with $\mathrm{OD}_{600}$ between 0.6 and 0.8 , the isopropyl $\beta$-D-1-thiogalactopyranoside (IPTG) inducer and the

Table 1 List of strains, plasmids, and oligonucleotide primers in this study

\begin{tabular}{|c|c|}
\hline Strains, plasmid, or primer & Description \\
\hline \multicolumn{2}{|l|}{ E. coli strains } \\
\hline $\mathrm{DH} 5 \mathrm{a}$ & $\mathrm{F}^{-}$recAl endA1 hsdR17( $\left.r_{k}^{-} m_{k}^{+}\right)$supE44 thi-1 gyrA relA1 \\
\hline BL21(DE3) & $\mathrm{F}^{-}$ompThsdS ${ }_{B}\left(r_{B}^{-} m_{B}^{-}\right)$galdcm (DE3) \\
\hline \multicolumn{2}{|l|}{ Plasmids } \\
\hline pET-32a & Amp ${ }^{r} \mathrm{~T} 7$ promoter trxA-tag His-tag T7 terminator lacl f1 pBR322 origin E. coli expression vector \\
\hline pET-28a & Kan $^{r}$ T7 promoter His-tag T7 terminator lacl f1 pBR322 origin E. coli expression vector \\
\hline $\mathrm{pET}-22 \mathrm{~b}$ & Amp ${ }^{r}$ T7 promoter pelB His-tag T7 terminator lacl f1 pBR322 origin E. coli expression vector \\
\hline \multicolumn{2}{|l|}{ Primers ${ }^{a}$} \\
\hline ZMd-lacB-Xhol-r & 5'-atCTCGAGTTTACTCACAGTAAAACCCG \\
\hline ZMd-lacB-Ncol-f & 5'-taCCATGGATCAAAGTAACACGCCTTC \\
\hline
\end{tabular}

a Nucleotides shown in underline represented the restriction sites 
a $\mathrm{pET} 28 \mathrm{a}$

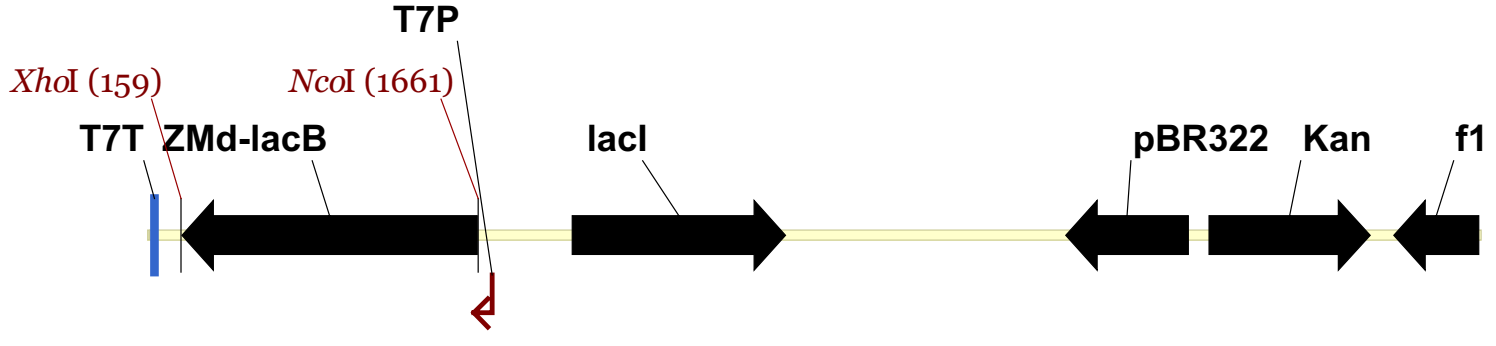

b $\mathrm{pET} 32 \mathrm{a}$

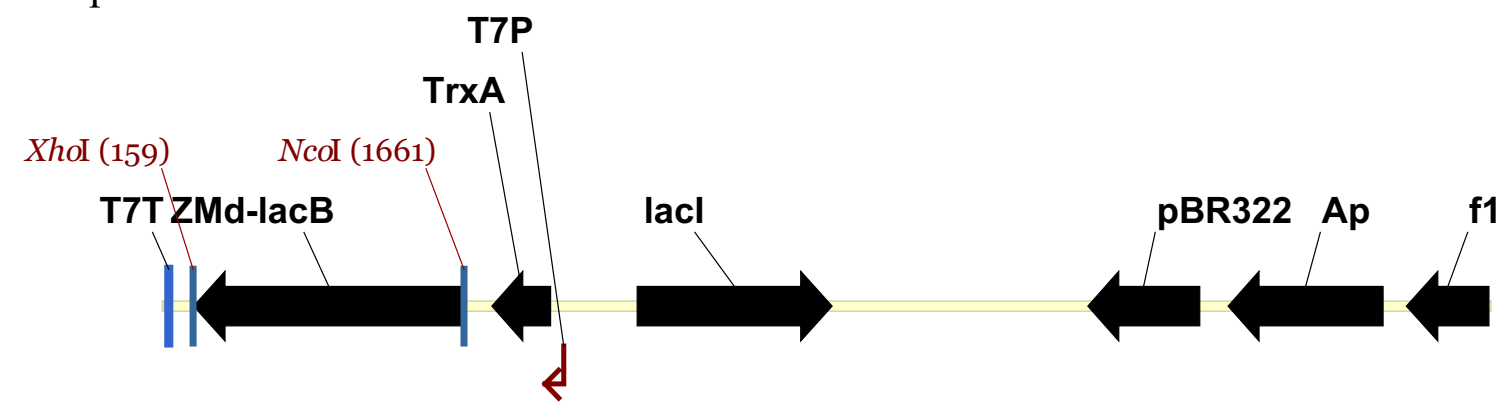

c $\mathrm{pET} 22 \mathrm{~b}$

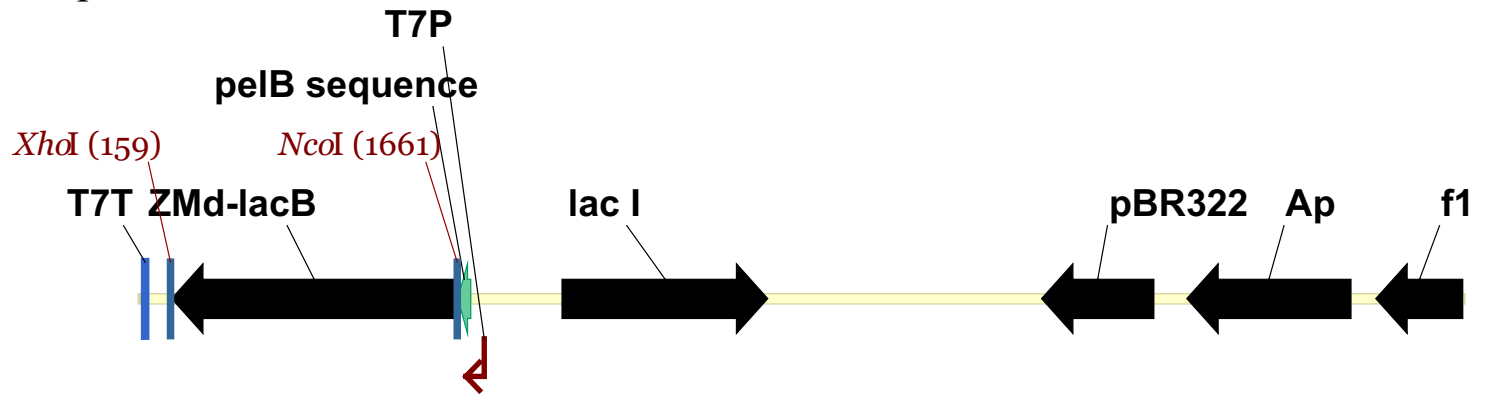

d

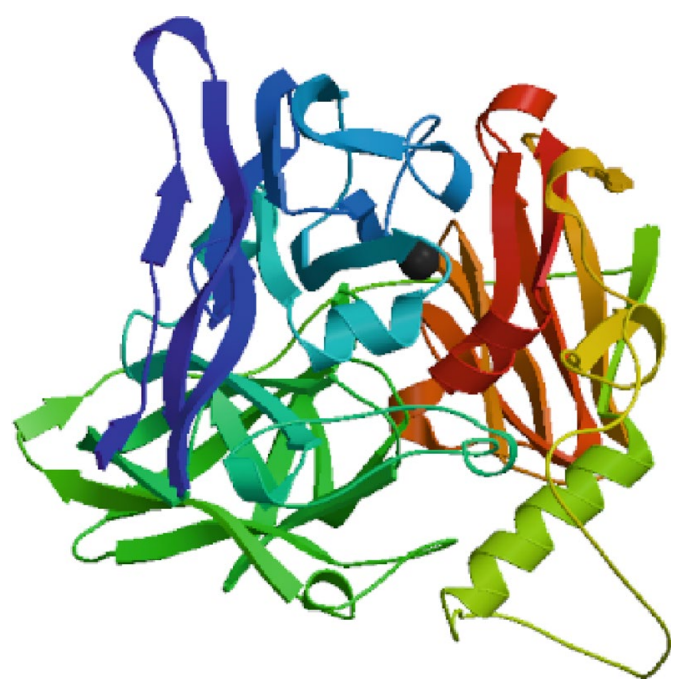

Fig. 1 Construction map for lacB in different vectors as a pET28a, b pET32a, and c pET22b and $\mathbf{d}$ molecular structure simulation of LacB via SWISSMODEL 
key factor $\mathrm{CuSO}_{4}$ were added to the cultures at a final concentration of $0.1 \mathrm{mM}$ and $0.5 \mathrm{mM}$, respectively. At this point, the incubation temperature was changed to $22{ }^{\circ} \mathrm{C}$ with the same agitation speed. After $12 \mathrm{~h}$ in culture, the recombinant bacteria were placed in an incubator at $22{ }^{\circ} \mathrm{C}$ without agitation for an additional $12 \mathrm{~h}$. For cell density analysis, sample was taken out from the broth to measure the optical density by a spectrophotometer at a wavelength of $600 \mathrm{~nm}$ (VersaMaxTM microplate reader, Molecular Devices, $\mathrm{CA}$ ). The $\mathrm{OD}_{600}$ values were converted to biomass in terms of $\mathrm{g} / \mathrm{L}$ via a calibration between optical density and dry cell weight. All the experiments were run in triplicate and designated as (A) +IPTG and $\mathrm{Cu},(\mathrm{B})+$ IPTG, and $(\mathrm{C})$ without induction, taking into consideration different cell fractions (i.e., $\mathrm{W}=$ whole cell, $\mathrm{S}=$ supernatant, $\mathrm{P}=$ pellet, and $\mathrm{M}=$ periplasm).

\section{Determination of MCO activity and protein concentration} MCO activity was determined by a spectrophotometric method based on the use of ABTS [2,2-azinobis(3ethylbenzothiazoline-6-sulfonic acid)] as substrate. To this end, a $200 \mu \mathrm{L}$ reaction mixture containing $100 \mu \mathrm{L}$ of $2 \mathrm{mM}$ ABTS, $95 \mu \mathrm{L}$ of $50 \mathrm{mM}$ reaction buffer (pH 3.0), and $5 \mu \mathrm{L}$ of enzyme solution was prepared. Enzyme activity was monitored with a spectrophotometer (VersaMax ${ }^{\mathrm{TM}}$ microplate reader, Molecular Devices, CA) set up at a wavelength of $420 \mathrm{~nm}$ (i.e., $\mathrm{OD}_{420}$ ) for the ABTS substrate. Reaction rates were calculated using a molar extinction coefficient of $36 \mathrm{mM} / \mathrm{cm}$. One unit was defined as the amount of enzyme that oxidized $1 \mu \mathrm{mol}$ of substrate per minute $(\mathrm{min})$. Protein concentrations were determined by the Bradford method (Bradford 1976), using bovine serum albumin as the standard.

\section{Protein expression determined by SDS-PAGE}

Proteins were run in gels prepared with $0.1 \%$ SDS, using $12 \%$ separating gel and $4 \%$ stacking gel. Tris-glycine buffer ( $\mathrm{pH}$ 8.3) containing 0.1\% SDS was used as electrode buffer. Samples at same concentration in terms of $\mathrm{OD}=5$ were treated with buffer and heated at $100{ }^{\circ} \mathrm{C}$ for $5 \mathrm{~min}$ before loading onto the gel. Electrophoresis was run from the cathode to the anode at a constant current of $20 \mathrm{~mA}$ per slab at room temperature in a Biorad mini gel electrophoresis unit. Proteins were visualized by staining with Coomassie blue R-250. Stained SDS gels were scanned on the Image scanner Labscan 6.0 (GE Healthcare). Subsequently, band intensities were quantified by densitometry, using the Quantity One 4.6.2 analysis software (BioRad).

\section{Biochemical characterization of $\mathrm{LacB}$}

LacB activity was analyzed using $2 \mathrm{mM}$ ABTS in $50 \mathrm{mM}$ sodium citrate buffer ( $\mathrm{pH} 2.2)$, and the reaction was incubated at a temperature range of $37-65{ }^{\circ} \mathrm{C}$. The crude enzyme of $\mathrm{MCO}$ was analyzed in $50 \mathrm{mM}$ buffer at variable pHs. Different concentrations of $\mathrm{CuSO}_{4}, \mathrm{CuCl}_{2}$, and $\mathrm{NaCl}$ were included in the ABTS substrate at a range of 0-2 mM.

\section{Purification of recombinant LacB}

The supernatant of the recombinant LacB solution produced from the pET28a-lacB vector in BL21(DE3) cells was loaded onto the AKTA system (GE, USA), using a His-trap affinity column for purification. The purified enzymes were put into a micro-centrifuge tube at 30-kDa molecular weight cut-off (GE, Millipore), to remove the imidazole and concentrate the solution for Au adsorption.

\section{Application of recombinant LacB on Au adsorption Adsorption of free Au ions}

Solutions containing $100 \mathrm{ppm}$ of $\mathrm{AuHCl}_{4}$ and $50 \mathrm{ppm}$ of purified recombinant LacB were prepared. Two milliliters of both solutions were mixed and agitated for $1 \mathrm{~h}$ at $70 \mathrm{rpm}$. Following agitation, $4 \mathrm{~mL}$ of the solution was transferred into the Amicon ${ }^{\circledR}$ device equipped with a $3 \mathrm{kDa}$ molecular cut-off filter and centrifuged for $25 \mathrm{~min}$. The resulting filtrate was used to measure the Au concentration by inductively coupled plasma with atomic emission spectroscopy (ICP-AES) (Thomas 2001).

\section{Adsorption of Au@NPs}

A solution containing $1 \mathrm{mM} \mathrm{AuHCl}$ and $38.8 \mathrm{mM}$ sodium citrate was prepared as follows: $60 \mathrm{~mL}$ of $\mathrm{AuHCl}_{4}$ solution was heated until boiling, followed by the addition of $6 \mathrm{~mL}$ of sodium citrate solution. Once the color of the solution changed from yellow to purple, the solution was left to cool at room temperature. This solution was the Au nanoparticle solution. Next, $300 \mu \mathrm{L}$ of Au nanoparticle solution and $200 \mathrm{ppm}$ of purified recombinant $\mathrm{LacB}$ were mixed together and agitated for $1 \mathrm{~h}$ at $70 \mathrm{rpm}$. Following agitation, $200 \mu \mathrm{L}$ of the solution was loaded into a 96-well plate to monitor the optical density with a spectrophotometer set up at a wavelength of 350-750 nm (VersaMax ${ }^{\mathrm{TM}}$ microplate reader, Molecular Devices, CA).

\section{Characterization of MCO-Au}

Zeta potential (Malvern Zetasizer Nano ZS, UK) was used to measure the isoelectric points of $\mathrm{MCO}$ or $\mathrm{MCO}$ with $\mathrm{Cu}\left(\mathrm{MCO}^{+\mathrm{Cu}}\right)$ following $\mathrm{Au}$ adsorption. The zeta potential was measured in $100 \mathrm{mM}$ phosphate buffer. 
Each sample was analyzed at least by triplicate. $\mathrm{MCO}^{+\mathrm{Cu}}$ and $\mathrm{MCO}^{+\mathrm{Cu}}$ after $\mathrm{Au}$ adsorption were further analyzed for their kinetic parameters against ABTS. The ABTS concentrations ranged from 0.01 to $2 \mathrm{mM}$ at $\mathrm{pH} 2.2$. The Michaelis-Menten kinetics was assumed and fitted by Lineweaver-Burk plot, using Sigmaplot 10.0 software.

\section{Nucleotide sequence accession number}

The sequences of $l a c B$ of $P$. hauseri ZMd44 have been deposited in the GenBank database under accession number JF718783.

\section{Results and discussion}

\section{Cloning Mco-lacB from P. hauseri ZMd44}

The full-length 1578 bp gene sequence encoding LacB, which included a signal peptide of 27 amino acids, was obtained from genomic annotation of the biodecolorizing bacterium, Proteus hauseri Zmd44 (Ng et al. 2013; Chen et al. 2010). Although the native multicopper laccase activity has been reported in $P$. hauseri (Zheng et al. 2013) and P. mirabilis (Olukanni et al. 2010), the heterologous expression of such kind of enzyme in $E$. coli has never been explored. Therefore, we cloned and overexpressed $l a c B$ in the $E$. coli for the first time. LacB exhibited activity after expression in the $\mathrm{pET} 22 \mathrm{~b}$ vector but it is not satisfying. LacB was shown to be a simple monomer by SWISS-MODEL simulation (Fig. 1d); therefore, this study focussed on the heterologous expression of LacB in different vectors.

\section{Mco-lacB expression in different vectors}

The constructions of recombinant protein were confirmed by enzymatic digestion with the restriction enzymes NcoI and XhoI. The triplicate results from the growth curves shown in Fig. 2 reveal that the addition of IPTG and $\mathrm{CuSO}_{4}$ into the cultures negatively affected cell growth. This could be due to two reasons: (i) the IPTG and copper ion may have a toxic impact on cell growth; (ii) the recombinant $\mathrm{pET} 22 \mathrm{~b}-\mathrm{lacB}$ may have higher toxicity in the cells owing to the signal peptide, pelB, which is secreted to the periplasm and accumulates copper, leading to cell death. Next, protein expression patterns detected by SDS-PAGE were different from those of the selected vectors, as shown in Fig. 3a. For pET28a, most of the recombinant LacB was soluble and had an estimated yield of $1330 \mathrm{mg} / \mathrm{L}$, as quantified by in-gel densitometry (Fig. 3a). However, LacB expression from the pET32a and pET22b vectors was found in the pellet (Fig. 3a). We speculate that the fusion protein TrxA expressed in the pET32a vector could have increased the load of the cells, resulting in the wrong folding of the MCO, which may become an inclusion body. On the other hand, in the pET22b vector, the recombinant $\mathrm{MCO}$ was expressed in the periplasm and also may have become an inclusion body. The time course of pET22b-lacB biomass shown in Fig. 2c indicates considerable cell death at $24 \mathrm{~h}$, whereas no cell lysis occurred in case of pET28a-lacB and pET32a-lacB. As shown in the activity analysis of Fig. $3 \mathrm{~b}$, the recombinant $\mathrm{MCO}$ expressed by pET28a had the highest activity among the three expression vectors. This activity was about 400 and $500 \mathrm{U} / \mathrm{L}$ at an optimal $\mathrm{pH}$ of 2.2 for whole cell and supernatant, respectively. This result was consistent with the color of the cell pellet obtained by centrifugation (Fig. 2d), where the chelation of copper ion represents a key event for MCO activity (Grass and Rensing 2001). In the case of the pET28a-lacB vector, copper ions can be transferred into the cell and combined with the MCO, generating a blue color (Fig. 2d) that translates into the highest MCO activity. Recently, a cell-free system to synthesize an active multicopper oxidase has been reported (Li et al. 2016). In such publication, the yield was almost $1.2 \mathrm{mg} / \mathrm{mL}$, which is as similar to the heterologous expression in the pET system. The alternative method to improve heterologous protein in $E$. coli can be accomplished by shifting to lower temperature and applied experimental design (Wu et al. 2017). In our strategy based on vector's property, we found that the best protein production came from the pET28a vector, which included neither the original signal peptide nor the pelB signal peptide from $\mathrm{pET} 22 \mathrm{~b}$ or fusion TrxA from pET32a in E. coli.

\section{MCO-lacB characterization}

The $\mathrm{pH}$ effect on crude $\mathrm{MCO}$ is shown in Fig. 3b. Increasing the $\mathrm{pH}$ value caused the $\mathrm{MCO}$ activity to drop dramatically. The best $\mathrm{pH}$ value was 2.2 , where MCO showed a 10-fold increase in activity when compared to its activity at $\mathrm{pH}$ 3.5. In the presence of ABTS, only single electron transfer takes place in the reaction instead of a proton transfer (Bertrand et al. 2002). Consequently, the optimal $\mathrm{pH}$ would be lower. The optimal temperature ranged from 55 to $65{ }^{\circ} \mathrm{C}$, as shown in Fig. 4a. In addition, the recombinant $\mathrm{MCO}$ showed relatively high activity in the range of $50-65{ }^{\circ} \mathrm{C}$. Compared to the native $\mathrm{MCO}$ of $P$. hauseri ZMd44 (Zheng et al. 2013), the recombinant MCO possessed a higher enzymatic activity and a wider thermo-resistance range. Therefore, the catalytic performance of $\mathrm{MCO}$ can be enhanced through heterologous expression, which increases its applicability in industry. Regarding the effect of the use of different ions (Fig. 4b), our results showed that the addition of copper ion $\left(\mathrm{CuSO}_{4}\right)$ at the optimal concentration of $0.5-1 \mathrm{mM}$ could increase MCO activity. However, addition of the copper ion at concentrations higher than $1 \mathrm{mM}$ resulted in an unexpected decrease of MCO activity. This suggests that the appropriate addition of the copper ion may help electrons to be transferred to the substrate, whereas an excess 

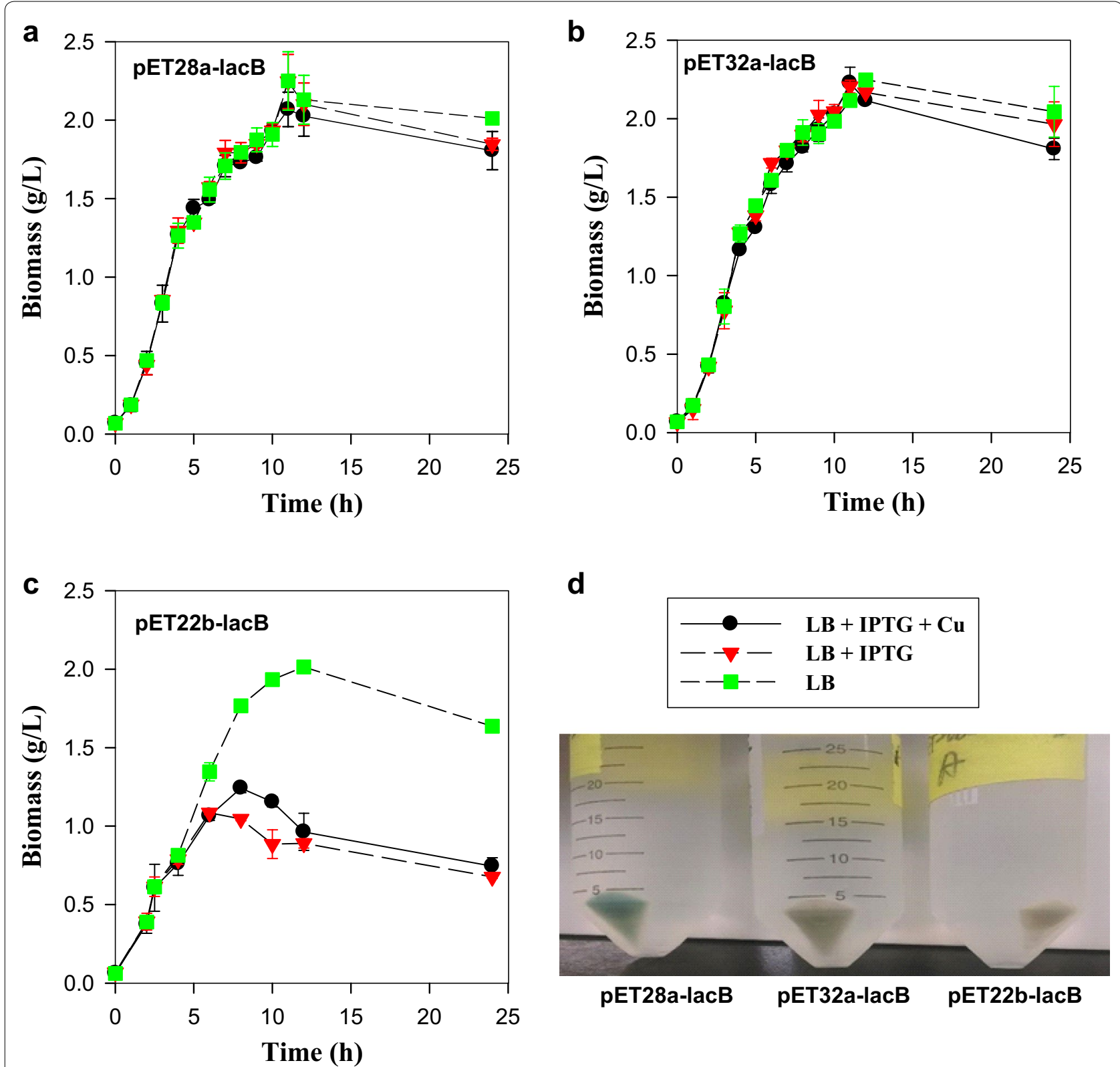

Fig. 2 Time course of biomass growth, using different expression vectors and conditions. Circles represent LB + IPTG and Cu, triangles represent LB + IPTG, and squares represent LB. a pET28a-lacB, b pET32a-lacB, c pET22b-lacB, and $\mathbf{d}$ cell pellets harvested after centrifugation

of copper ion may become an obstacle and may slow down the rate of electron transfer. Although the catalytic activity of MCOs can be enhanced by copper addition, the inhibition of such activity by chloride ion became more evident upon addition of copper (II) chloride and sodium chloride. As the chloride ion was added in the reaction system, the $\mathrm{MCO}$ activity dropped dramatically in spite of the presence of copper ion. Other groups have reported similar results in which MCO activity could be strongly inhibited by the chloride ion (Naqui and Varfolomeev 1980; Kepp 2015).

Recently, Sondhi et al. reported that the strain Bacillus tequilensis $\mathrm{SN} 4$ had the highest catalytic activity of $\mathrm{MCO}$ (i.e., $k_{\text {cat }}$ is $4020 / \mathrm{min}$ ) at pH 5.5 and $85^{\circ} \mathrm{C}$ (Sondhi et al. 2014). As shown in Table 2, the reaction conditions of $\mathrm{MCO}$ activity are very diverse among different microbes (Ye et al. 2010; Ausec et al. 2015; Yang et al. 2016; Safary et al. 2016). However, rare forms of MCO 


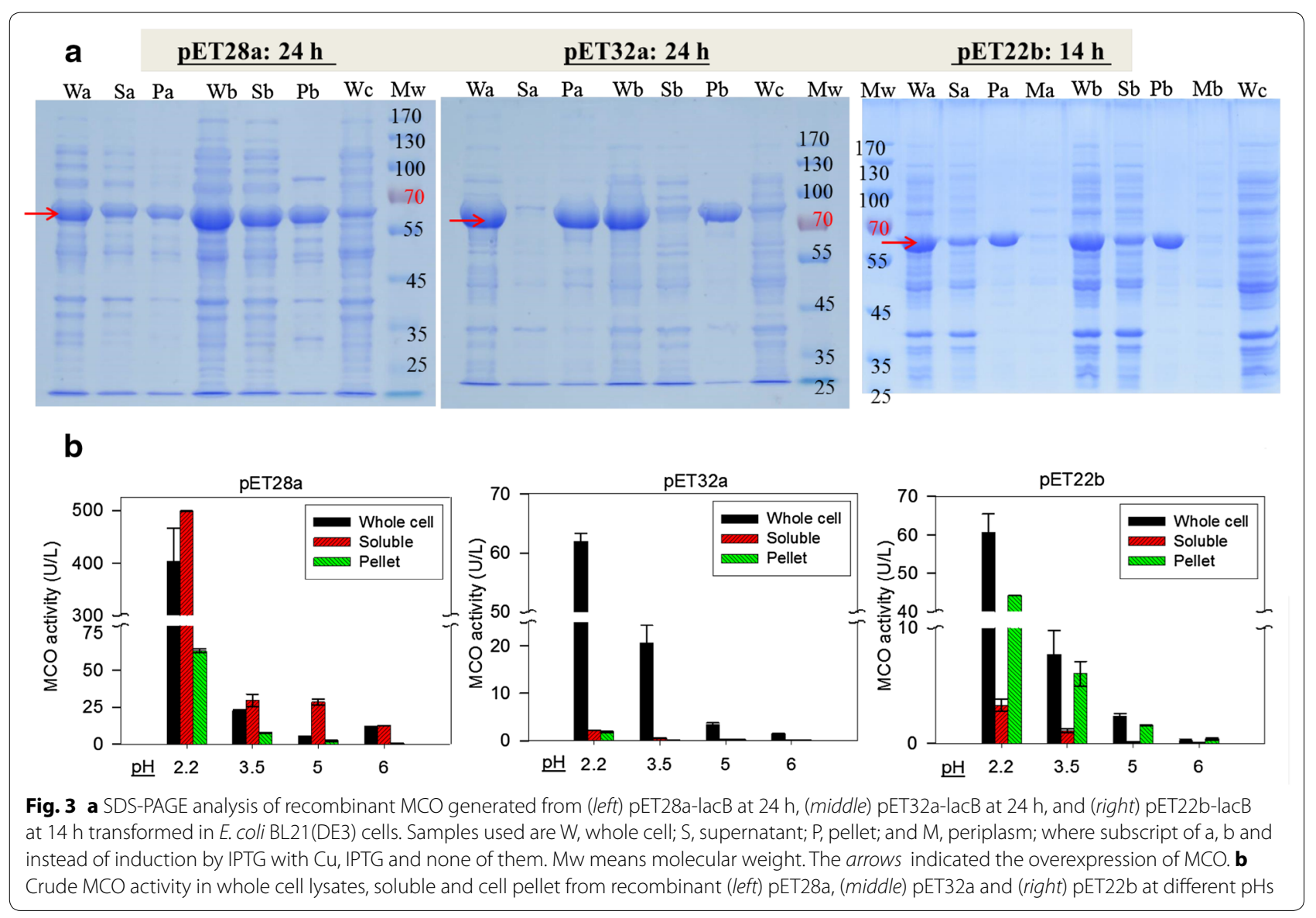

a

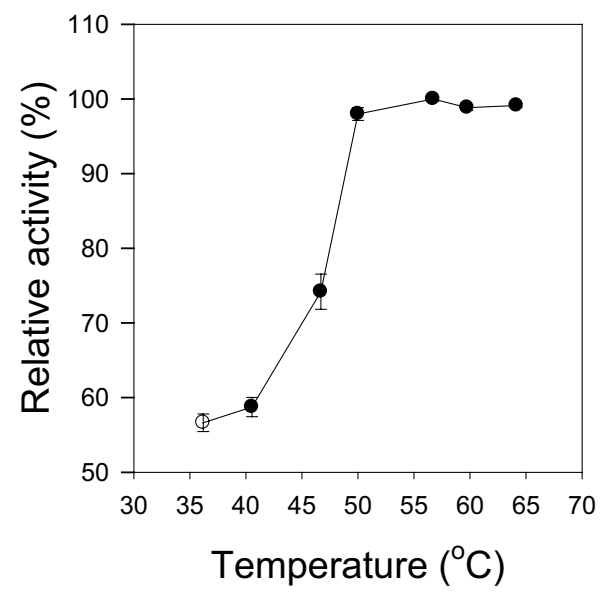

b

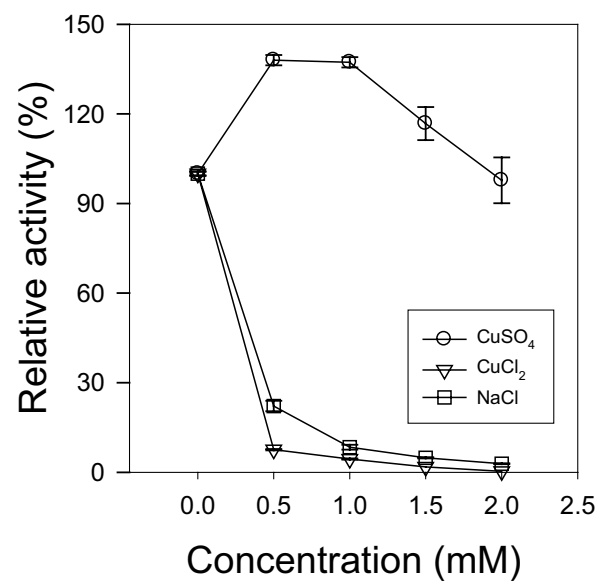

Fig. 4 Characterization of recombinant crude LacB. a Effect of incubation temperature on MCO activity. $\mathbf{b}$ Effect of metal ion addition on MCO activity 
Table 2 Comparison of the catalytic kinetic parameters of MCO on ABTS from different microorganisms

\begin{tabular}{|c|c|c|c|c|c|c|c|}
\hline Sources & Gene & $\begin{array}{l}\mathrm{V}_{\max } \\
\mu \mathrm{mol} / \mathrm{min}\end{array}$ & $\begin{array}{l}k_{\text {cat }} \\
1 / \mathrm{min}\end{array}$ & $\begin{array}{l}K_{m} \\
\mathrm{mM}\end{array}$ & $\begin{array}{l}k_{\text {cat }} / K_{m} \\
1 / \mathrm{mM}^{\mathrm{a}} / \mathrm{min}\end{array}$ & Reaction condition & Reference \\
\hline Bacillus tequilensis SN4 & SN4LAC & ND & 4020 & 1.4 & 2871 & $\mathrm{pH} 5.5$ at $85^{\circ} \mathrm{C}$ & Sondhi et al. (2014) \\
\hline Mangrove soil & $\operatorname{Lac591^{a}}$ & ND & 2.52 & 0.09 & 28.0 & $\mathrm{pH} 7.4$ at $55^{\circ} \mathrm{C}$ & Ye et al. (2010) \\
\hline Thioalkalivibrio sp. ALRh & lacc & 1500 & 129 & 4.6 & 28.0 & $\mathrm{pH} 5$ at $50^{\circ} \mathrm{C}$ & Ausec et al. (2015) \\
\hline Pseudomonas sp. 593 & cumA & ND & 23.58 & 0.1 & 235.8 & $\mathrm{pH} 5$ at $55^{\circ} \mathrm{C}$ & Yang et al. (2016) \\
\hline Bacillus sp. SL-1 & $\cot A$ & ND & 1380 & 0.046 & 30,000 & $\mathrm{pH} 4.5$ at $50^{\circ} \mathrm{C}$ & Safary et al. (2016) \\
\hline Proteus hauseri & $\operatorname{LacB}^{a}$ & 58 & 1328 & 0.303 & 4382 & $\mathrm{pH} 2.2$ at $50^{\circ} \mathrm{C}$ & This study \\
\hline Proteus hauseri & $\mathrm{LacB}-\mathrm{Au}{ }^{\mathrm{b}}$ & 5.59 & 52.7 & 0.129 & 408.5 & $\mathrm{pH} 2.2$ at $50^{\circ} \mathrm{C}$ & This study \\
\hline
\end{tabular}

a The yields of LacB of Proteus hauseri and Lac591 of Mangrove soil expressed in E. coli are 1330 and $1381 \mathrm{mg} / \mathrm{L}$, respectively

b LacB-Au means with gold binding and followed by activity analysis

show acidophilic properties and accordingly our results of $P$. hauseri MCO had optimal activity at $\mathrm{pH}$ 2.2. More importantly, this is the first attempt to detect the goldbinding properties of this MCO. The enzymatic activity was highly inhibited after addition of $\mathrm{AuHCl}_{4}$ because of chloride inhibition. Finally, the $\mathrm{Au}$ ion was from $\mathrm{AuHCl}_{4}$; thus, the Vmax of LacB is tenfold than that of LacB$\mathrm{Au}$ (Table 2), which represented the chloride inhibition was dominating. This mechanism when gold binding to enzyme will be discussed in the next section.

\section{Application and characterization of recombinant MCO-lacB for Au adsorption}

It has been reported that $\mathrm{Au}$ nanoparticle could be adsorbed on MCO and function as a switch on ABTS reaction (Guo et al. 2015). We attempted to evaluate the ability of recombinant MCOs to adsorb Au following two approaches: free ion and nanoparticle. Purified recombinant $\mathrm{MCO}$ was used for Au ion adsorption experiments (Fig. 5a). This showed that 37 and 39\% $\mathrm{Au}(\mathrm{mg})$ was adsorbed per milligram of $\mathrm{MCO}$ with $(\mathrm{Sa})$ and without $(\mathrm{Sb})$ copper ion in significant level $(P$ value $<0.05)$. MCOs supplemented with copper ion possessed a very similar ratio of Au adsorption. This adsorption percentage is relatively higher than other protein for gold adsorption. Maruyama et al. applied three proteins to adsorb the gold ion, which showed that the adsorption percentage is $3.6,4$, and $1.6 \%$ for ovalbumin, BSA, and lysozyme, respectively (Tatsuo et al. 2007). Actually, in the Au biorecovery research, some reports revealed that a specific peptide bond on the gold surface $(1,1,1)$ but not adsorbed of gold ions (Brown 1997, 2000). Alternatively, the adsorption of Au nanoparticles (Au@NPs) on MCO was similar in the presence or absence of copper ion (Fig. 5b). The Au@NPs were directly adsorbed on the MCO's surface, as the adsorption ability is totally determined by the surface property. As shown in Fig. 5b, the adsorption of Au@NPs showed a peak at a wavelength of
$530 \mathrm{~nm}$, and the optical density increased as the recombinant $\mathrm{MCO}$ was added to the culture. Adsorption of Au@NPs on the MCO could have caused a blockade of the light pathway, and as a result, there would be an increase in optical density.

The initial working conditions of $\mathrm{MCO}$ and $\mathrm{MCO}^{+\mathrm{Cu}}$ (i.e., cultured with $\mathrm{Cu}$ ) for adsorbing $\mathrm{Au}$ were determined at $\mathrm{pH} 7.75$ and 7.73, respectively. However, the zeta potential of both samples following Au adsorption was determined at different $\mathrm{pHs}$. These results are shown in Fig. 5c. The isoelectric points of $\mathrm{MCO}$ and $\mathrm{MCO}^{+\mathrm{Cu}}$ were determined at $\mathrm{pH} 5.29$ and $\mathrm{pH} 5.51$, respectively. This showed that the recombinant proteins were anionic and the $\mathrm{Au}$ adsorption on the protein was through electrostatic interactions. The isoelectric points of $\mathrm{MCO}$ and $\mathrm{MCO}^{+\mathrm{Cu}}$ upon $\mathrm{Au}$ adsorption were determined at $\mathrm{pH}$ 6.21 and 6.15 , respectively. At this point, the proteins were still anionic, but the isoelectric point shifted to a higher $\mathrm{pH}$, especially for MCO. We suggest that Au ions compete for the same binding site within the protein, affecting the chelation of the copper ion by the MCO and causing structural changes. Higher isoelectric points showed that, at the same $\mathrm{pH}$, there were fewer negative charges of the protein after $\mathrm{Au}$ adsorption. This is consistent with the fact that $\mathrm{Au}$ possesses protons combined to the proteins, which partially neutralize the protein's negative charges.

\section{Conclusion}

We optimized the heterologously expression of $\mathrm{MCO}$ and investigated the extent of its applications. Among the three different vectors analyzed in this study (i.e., pET28a, pET22b, and pET32a), pET28a, carrying the lac $B$ gene, showed the best results regarding expression levels, cell growth, and enzyme activity at different pHs. The optimal $\mathrm{pH}$ of the recombinant $\mathrm{MCO}$ was 2.2 at an incubation temperature of $55^{\circ} \mathrm{C}$ with the addition of $0.5 \mathrm{mM}$ of copper. We also found that the addition of chloride ion strongly inhibited MCO activity. This is 
a

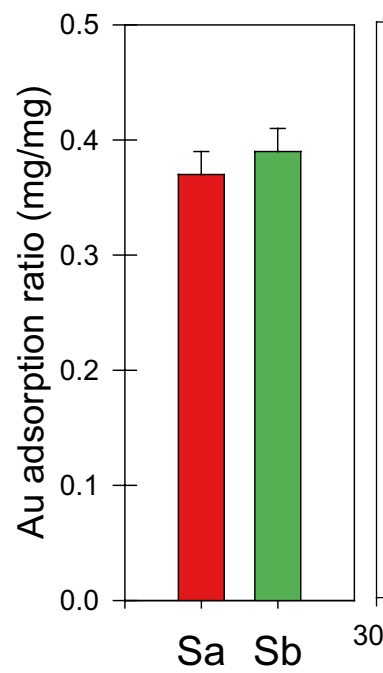

b

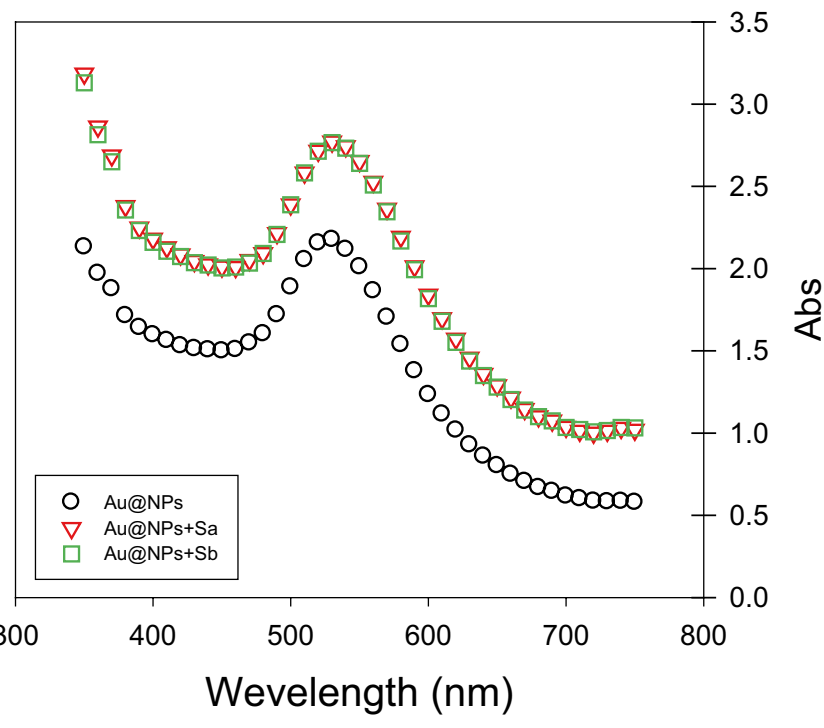

C

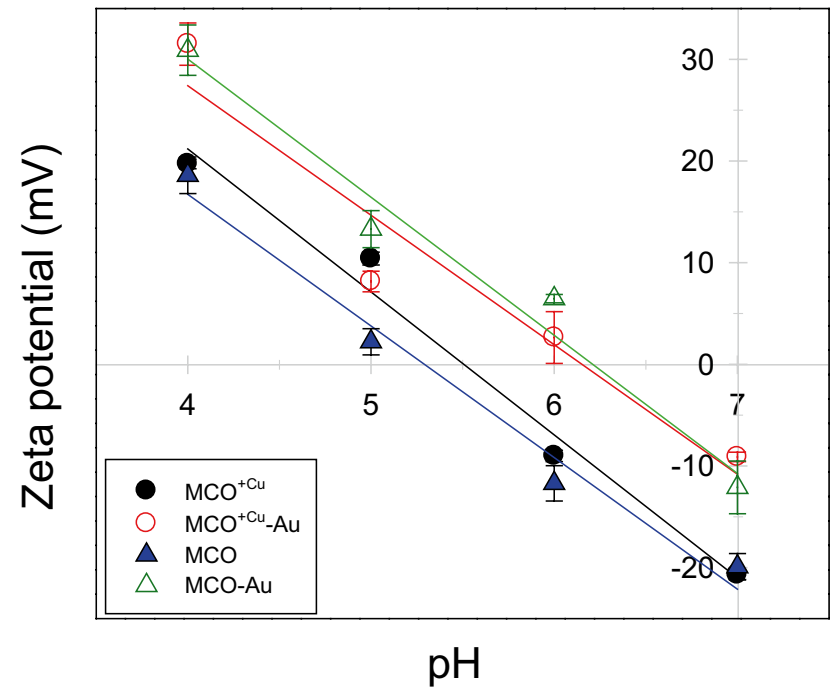

Fig. 5 Application of recombinant LacB in Au adsorption. a Supernatant fractions of MCO produced by BL21 cells harboring the pET28a-lacB vector under IPTG and copper (Sa), or IPTG only (Sb). b Spectrum scanning of free Au@NPs or Au@NPs adsorption by Sa and Sb. c Zeta potential analysis of $\mathrm{MCO}$ and $\mathrm{MCO}^{+\mathrm{Cu}}$ before and after adsorption of $\mathrm{Au}$

the first attempt to explore the ability of MCO from $P$. hauseri to adsorb Au or Au@NPs, which may become a novel application for bioremediation in the future.

\section{Authors' contributions}

IS and SI designed the experiment and analyzed the data, SI performed most of experiments in genetic section, and YJ did the major part of gold adsorption. IS and SI wrote the manuscript. All authors read and approved the final manuscript.

\section{Author details}

${ }^{1}$ Department of Chemical Engineering, National Cheng Kung University, Tainan 70101, Taiwan. ${ }^{2}$ Research Center for Energy Technology and Strategy, National Cheng Kung University, Tainan 70101, Taiwan.

\section{Acknowledgements}

Not applicable.

Competing interests

The authors declare that they have no competing interests. 


\section{Availability of data and materials}

The authors have agreed to provide the data and materials for open access.

\section{Consent for publication}

The authors approved the consent for publishing the manuscript.

\section{Ethics approval and consent to participate}

All the authors have read and agreed the ethics for publishing the manuscript.

\section{Funding}

This work was support by the Ministry of Science and Technology (MOST 105-2221-E-006-225-MY3 and MOST 105-2621-M-006-012-MY3) in Taiwan.

\section{Publisher's Note}

Springer Nature remains neutral with regard to jurisdictional claims in published maps and institutional affiliations.

Received: 23 March 2017 Revised: 11 April 2017 Accepted: 13 April 2017 Published online: 22 April 2017

\section{References}

Ausec L, Črnigoj M, Šnajder M, Ulrih NP (2015) Characterization of a novel high-pH-tolerant laccase-like multicopper oxidase and its sequence diversity in Thioalkalivibrio sp. Appl microbiol biotechnol 99(23):9987-9999

Baneyx F, Mujacic M (2004) Recombinant protein folding and misfolding in Escherichia coli. Nat Biotechol 22(11):1399-1408

Bertrand T, Jolivalt C, Briozzo P, Caminade E, Joly N, Madzak C, Mougin C (2002) Crystal structure of a four-copper laccase complexed with an arylamine: insights into substrate recognition and correlation with kinetics. Biochemistry 41(23):7325-7333

Bradford MM (1976) A rapid and sensitive method for the quantitation of protein utilizing the principle of protein-dye binding. Anal Biochem 72(1-2):248-254

Brown S (1997) Metal-recognition by repeating polypeptides. Nat Biotechnol 15:269-272

Brown S, Sarikaya M, Johnson E (2000) A genetic analysis of crystal growth. J Mol Biol 299(3):725-735

Chen BY, Zhang MM, Chang CT, Ding Y, Lin KL, Chiou CS, Hsueh CC, Xu H (2010) Assessment upon azo dye decolorization and bioelectricity generation by Proteus hauseri. Bioresour Technol 101(12):4737-4741

Chen BY, Wang YM, Ng IS, Liu SQ, Hung JY (2012) Deciphering simultaneous bioelectricity generation and dye decolorization using Proteus hauseri. J Biosci Bioeng 113(4):502-507

Claus H (2003) Laccases and their occurrence in prokaryotes. Arch Microbiol 179(3):145-150

Gopal GJ, Kumar A (2013) Strategies for the production of recombinant protein in Escherichia coli. Protein J 32(6):419-425

Grass G, Rensing C (2001) CueO Is a multi-copper oxidase that confers copper tolerance in Escherichia coli. Biochem Biophys Res Commun 286(5):902-908

Guo S, Li H, Liu J, Yang Y, Kong W, Qiao S, Huang H, Liu Y, Kang Z (2015) Visiblelight-induced effects of Au nanoparticle on laccase catalytic activity. ACS appl mater inter 7(37):20937-20944

Kepp KP (2015) Halide binding and inhibition of laccase copper clusters: the role of reorganization energy. Inorg Chem 54(2):476-483

Larsson S, Cassland P, Jonsson LJ (2001) Development of a Saccharomyces cerevisiae strain with enhanced resistance to phenolic fermentation inhibitors in lignocellulose hydrolysates by heterologous expression of laccase. Appl Environ Microb 67(3):1163-1170

Li D, Lv P, Zhu J, Lu Y, Chen C, Zhang X, Wei Q (2015) NiCu alloy nanoparticleloaded carbon nanofibers for phenolic biosensor applications. Sensors 15(11):29419-29433
Li J, Lawton TJ, Kostecki JS, Nisthal A, Fang J, Mayo SL, Rosenzweig AC, Jewett MC (2016) Cell-free protein synthesis enables high yielding synthesis of an active multicopper oxidase. Biotechnol J 11(2):212-218

Mayer AM, Staples RC (2002) Laccase: new functions for an old enzyme. Phytochemistry 60(5):551-565

Moreira GM, Cunha CE, Salvarani FM, Goncalves LA, Pires PS, Conceicao FR, Labato FC (2014) Production of recombinant botulism antigens: a review of expression systems. Anaerobe 28:130-136

Naqui A, Varfolomeev SD (1980) Inhibition mechanism of Polyporus laccase by fluoride ion. FEBS Lett 113(2):157-160

Natarajan G, Ting YP (2014) Pretreatment of e-waste and mutation of alkalitolerant cyanogenic bacteria promote gold biorecovery. Bioresour Technol 152:80-85

Natarajan G, Ting YP (2015) Gold biorecovery from e-waste: an improved strategy through spent medium leaching with pH modification. Chemosphere 136:232-238

Ng IS, Zheng X, Chen BY, Chi X, Lu Y, Chang C (2013) Proteomics approach to decipher novel genes and enzymes characterization of a bioelectricitygenerating and dye-decolorizing bacterium Proteus hauseri ZMd44. Biotechnol Bioproc Eng 18:8-17

Ng IS, Chen T, Lin R, Zhang X, Ni C, Shun D (2014) Decolorization of textile azo dye and congo red by an isolated strain of the dissimilatory manganesereducing bacterium Shewanella xiamenensis BC01. Appl Microbiol Biotechnol 98(5):2297-2308

Ng IS, Isaac NC, Zhou Y, Wu X (2015) Cultural optimization and metal effects of Shewanella xiamenensis $\mathrm{BC} 01$ growth and swarming motility. Bioresour Bioprocess 2:28-37

Olukanni OD, Osuntoki AA, Kalyani DC, Gbenle GO (2010) Decolorization and biodegradation of Reactive Blue 13 by Proteus mirabilis LAG. J Hazard Mater 184(1-3):290-298

Rodgers CJ, Blanford CF, Giddens SR, Skamnioti P, Armstrong FA, Gurr SJ (2010) Designer laccases: a vogue for high-potential fungal enzymes? Trends Biotechnol 28(2):63-72

Rosano GL, Ceccarelli EA (2014) Recombinant protein expression in Escherichia coli: advances and challenges. Front Microbiol 5:172

Safary A, Moniri R, Hamzeh-Mivehroud M, Dastmalchi S (2016) A strategy for soluble overexpression and biochemical characterization of halo-thermotolerant Bacillus laccase in modified E. coli. J Biotechnol 227(227):56-63

Santhanam N, Vivanco JM, Decker SR, Reardon KF (2011) Expression of industrially relevant laccases: prokaryotic style. Trends Biotechnol 29(10):480-489

Sondhi S, Sharma P, Saini S, Puri N, Gupta N (2014) Purification and characterization of an extracellular, thermo-alkali-stable, metal tolerant laccase from Bacillus tequilensis SN4. PLoS ONE 9:e96951

Tatsuo M, Hironari M, Yukiko S, Ichiro K, Misa H, Saori S, Noriho K, Masahiro G (2007) Proteins and protein-rich biomass as environmentally friendly adsorbents selective for precious metal ions. Environ Sci Technol 41(4):1359-1364

Thomas R (2001) A beginner's guide to ICP-MS. Spectroscopy 16:38-42

Wang N, Ng IS, Chen PT, Li Y, Chen YC, Chen BY, Lu Y (2014) Draft genome sequence of the bioelectricity-generating and dye-decolorizing bacterium Proteus hauseri strain ZMd44. Genome Announc 2(1):e00992-e009913

Wu Z, Hong H, Zhao X, Wang X (2017) Efficient expression of sortase A from Staphylococcus aureus in Escherichia coli and its enzymatic characterizations. Bioresour Bioprocess 4:13-22

Yang S, Long Y, Yan H, Cai H, Li Y, Wang X (2016) Gene cloning, identification and characterization of the multicopper oxidase CumA from Pseudomonas sp. 593. Biotechnol Appl Bioc. doi:10.1002/bab.1501

Ye M, Li G, Liang WQ, Liu YH (2010) Molecular cloning and characterization of a novel metagenome-derived multicopper oxidase with alkaline laccase activity and highly soluble expression. Appl Microbiol Biot 87(3):1023-1031

Zheng X, Ng IS, Ye C, Chen BY, Lu Y (2013) Copper ion-stimulated McoA-laccase production and enzyme characterization in Proteus hauseri ZMd44. J Biosci Bioeng 115(4):388-393 